\title{
HYDROMORPHOLOGY OF THE UNCONFINED GROUNDWATER IN THE SOUTH OF KLATEN DISTRICT \\ (Data before Earthquake Mei $27^{\text {th }} 2006$ )
}

by:

\author{
Langgeng Wahyu Santosa \\ Physical Geography Department, Faculty of Geography, Barek Street, \\ North Skip, Bulak Sumur, Gadjah Mada University, Yogyakarta \\ Phone (0274) 6492332, Fax (0274) 6492348 \\ E-mail: wahyus_72@yahoo.co.id
}

\begin{abstract}
Cort

Shere are some characteristics and distributions of unconfined groundwater variation in the research area. Those are related to a system of water supply and consumptive use for drinking water. Variation of the groundwater characteristic depends on variation of morphology. Therefore, it is needed to delineate bydromorphology units of the regions as a base on groundwater resources management, especially for drinking water.

The aims of the research are: (1) to study of the characteristic and distribution of unconfined groundwater variations base on landform units, (2) to study the factors that affect such variations, and (3) to establish the bydromorphology units of the regions for groundwater resources management, especially for drinking water. The method used in this research is landform approach and field survey. The sampling method is stratified sampling, based on landform as the analysis approach.

Result of the research shows that there are some variations of groundwater characteristic at each landform. Landforms which have good groundwater characteristic are Hydromorphology Unit of Fluvio Volcanic Plain of Young Merapi (except Bayat region) and Hydromorphology Unit of Volcanic Foot Plain of Young Merapi. At those units, there are good quality of groundwater, bicarbonate water (bydrochemical type I), having low electric conductivity, shallow of water table, low in fluctuation, and middle to fast class in aquifer permeability. Those units are the most potential unconfined groundwater resources management for drinking water. The units which have poor groundwater characteristic are Hidromorphology Unit in Bayat Region, including Undulating Alluvial Plain, Fluvio Volcanic Plain of Young Merapi, and Swamp Alluvial Plain. Generally, the groundwater quality is medium to poor, the bydrochemical type is V a (initiation process of connate water) and type III (evaporate water), shallow up to medium of water table, and low to middle class of aquifer permeability. The taste of groundwater is brackish to saline with high concentration of chloride.
\end{abstract}

Keywords: Hydromorphology, Hydrochemical, Unconfined groundwater, Landform

\section{INTRODUCTION}

\section{Background}

Groundwater issue is a complicated study and has important meaning for human being, especially for the use of drinking water need or other need. The planning of usage, management, and groundwater conservation are needed in the light of the importance of this natural resource for the living. Therefore, it is important to study groundwater in order to afford the planning of groundwater usage and management. Various approaches can be taken in this effort, such as using hydrogeomorphology study. This study emphasizes in the concept that each certain morphological condition, reflected by its landform, will have certain response to the groundwater characteristic inside it. A landform of a region 
is characterized by the present of earth surface topography or relief, the genesis, geomorphologic structure, and its compounding material. Each compounding material of the landform will affect the groundwater condition, either the quality, the depth of groundwater surface (water table), groundwater movement, hydro-chemical type, or its aquifer permeability. Hence, the condition of groundwater in a region can be shown with the hydromorphological condition of that region.

The characteristic and the distribution of unconfined groundwater in Southern Klaten District is interesting enough and needs to get attention in the relation with the effort of primary water providence. In certain locations, such as in Bayat, groundwater is difficult to obtain with well condition, there is brackish or even salty groundwater, causing low quality of groundwater and not good from drinking water resource. In several places, the citizen has to take water from the spring in other place for the need of drinking water or other household needs. Meanwhile, in other area, the groundwater condition is still good enough, but there is only a problem on the high fluctuation of water table between dry and rainy season. In rainy season, the groundwater is shallow enough and easily obtained, but in several area, in dry season, there are many dried wells (the groundwater surface goes down dramatically). Such a condition is certainly affected by geomorphologic and geologic general condition of the district. The existence of salty water (low quality of groundwater) is possibly affected by the genesis of the region, and related to its content litology. The difference of high fluctuation groundwater between one place and another is possibly affected by the condition of different containing materials, the variation of structure and geomorphologic process, and also by different sedimentation environment.

The geomorphologic condition and the genesis of a region seem to have a main role in the difference of unconfined groundwater characteristic in this region. In the unit dominated by volcanic materials of Young Merapi relatively has better groundwater condition than the groundwater condition in the unit of ex swamp alluvial plain, such as existing in Western Gantiwarno Sub District. This unconfined groundwater condition will have difference directing to the east following the stream of Dengkeng River, and the getting lower of its quality in Bayat, especially in ex swamp alluvial plain around Jombor Swamp. Such a groundwater condition is interesting to study, related to the effort to plan the groundwater usage and primary water providence system from drinking water in southern Klaten District.

The research field was included in southern Klaten District, including Prambanan, Gantiwarno, Wedi, and Bayat Sub Districts, in fact has various morphological views, arranged by various litology, and formed by the effect of various activities or geomorphologic process working either in the past or recently. Complex morphological representation clearly will describe the variation of existence and its groundwater characteristic. Unconfined groundwater hydromorphology study has a very important meaning as the initial step in planning the usage and the management of groundwater resource.

Complex morphological representation in the research area showed the variation of the existing landform unit. The 
landform unit is comprised of the aspect of relief or topography, structure, and the geomorphologic process (genesis), and its compounding materials. The varia-tion of landform representation will show the variation of groundwater and its charac-teristic, shown by its hydromorphology unit.

\section{Problem Formulation}

Based on its genesis, the formulation of southern Klaten District landform (Bayat and the surrounding) is affected by two factors, the process started from PreTersier era, in the form of sea trough, and followed by the process of fluvio-volcanic of Young Merapi up to now (Bemmelen, 1970). As the result of gradual tectonic stages, according to Hadi Sutomo (1990), it causes various morphological representations, which can be controlled by the structure and the type of rock compounding it. Oceanic plate movement, the activities of volcano (fluvio-volcano) and geomorphic power working in sequence, results total change in the research field generally from a shallow sea (lithoral zone) into a land with various morphological representations recently. Such a condition will affect the variation of groundwater characteristic and providence, results another problem for the citizen in obtaining primary water, especially for drinking water.

Based on this problem, it reveals question on: "Why there is variation and groundwater providence in this area?" Based on this formulation, it occur several research questions, which can be studied further:

(a) How are the variation of characteristic and the distribution pattern of unconfined groundwater in the research area?

(b) What factors affecting the characteristic and the distribution pattern of un- confined groundwater in the research area?

(c) How is the effort to plan the usage and the management of groundwater resource, its relation with the priority of primary water for drinking water?

To answer those questions, one of the approaches taken in order to overcome the problem and formulate the direction of groundwater usage plan for drinking and primary water providence system is to arrange hydromorphology unit.

\section{RESEARCH OBJECTIVES}

Based on the research's problem above, thus this study has main objectives of:

(1) Studying the characteristic variation and the distribution pattern of unconfined groundwater in the research field based on its landform unit;

(2) Finding out and studying the factors affecting the characteristic variation and the distribution of unconfined groundwater in the research area; and

(3) Managing hydromorphology units in research area as the basis for the arrangement of direction priority of the use of groundwater, especially unconfined groundwater for the primary water need of the people in research area.

\section{THEORETICAL REVIEW AND FRA- MEWORK}

\section{Theoretical Review}

To explain the availability of groundwater, it needs an explanation about where and how the groundwater exists. It also needs prediction of distribution under the surface. Geological terms have important meaning in groundwater hydrology. 
Groundwater is water located inside of the pores in geological layer (Todd, 1980). Unconfined groundwater is groundwater existing on the impermeable layer up to the water table under the land surface. Several important aspects related to groundwater is geomorphology, including in it is geology affecting the distribution of groundwater, hydrologic cycle determining the supply into the ground, and fluid mechanical about its movement. These three factors have strong effect to the position and the condition of groundwater (Soemarto, 1988).

Groundwater exists in several geological types. One of the most important is aquifer, a rock formation that can keep and release groundwater in adequate amount (Todd, 1980). The character of the ability of a rock layer to release water, related to the water movement in the pores of the rock is called as permeability. This is the thing affecting the reservoir potential or groundwater discharge in aquifer. The rock characteristic and the ability of aquifer strongly determine the quality and quantity of groundwater existing in it. One of the geomorphologic approaches to study groundwater is the arrangement of hydromorphology unit, as stated by Verstappen and Zuidam (1968) in Sutikno (1992). This is caused by the main component of geomorphology are the factors affecting the characteristic of groundwater.

Hydromorphology unit is a groundwater unit reflected by the condition of its geomorphology with landform unit as the basic of main analysis. According to de Rider (1972) and Sutikno (1989), landform unit, generally will affect the distribution of groundwater. Landform unit is shown by topography and litology of a region, while topography of a region is controlled by the geological structure underneath (Robert, 1982). One of the morphological features of research area is the process variation, structure, and arranging litology or materials. The variation or the difference of litology will affect the difference of groundwater quality (Hem, 1970), and the aquifer permeability coefficient as the measurement to the relative potential of groundwater (Todd, 1980). Based on this though, thus the landform unit can be used as the basic for the arrangement of hydromorphology unit, especially in unconfined groundwater study.

Based on the concepts and theoretical above, there area 5 factors influenced the hydrogeomorphology characteristics of the groundwater, i.e. (i) the genesis or origin of the landscape; (ii) sedimentation environment; (iii) mineral composition of the aquifer materials; (iv) process and pattern of groundwater flow; and (v) time living of groundwater in the aquifer (Hem, 1970; de Rider, 1972; Meijerink, 1982; Todd, 1980; Fetter, 1988; Stuyfzand, 1991; Sutikno, 1992; Appelo dan Postma, 1994; Lawrence, et al., 2000; Acworth, 2001; Gabriela-Garcia, et al., 2001; Martinez and Bocanegra, 2002; Ahmed and Krishnamurthy, 2004; Cartwright and Weaver, 2005).

\section{Theoretical Framework}

Important aspects including in hydrogeomorphology study is geological condition (structure, stratigraphy, and litology), and geomorphology (morphology, process or genesis, morpho-structure, and morpho-arrangement). Those factors affect the characteristic and the distribution of groundwater (dept of water table, electric conductivity distribution, quality, hydrochemical type, and aquifer permeability). 
Morphology determines the size and the form (configuration) of earth surface, affecting the availability, event, and the direction of unconfined groundwater movement. The topographical change on the surface will affect on the direction of the movement and the depth of surface of unconfined groundwater. Morpho-process (genesis) affects the permeability, porosity, infiltration, spring distribution, and the recharge area. Morpho-structure also affect the position of water table and the direction of groundwater movement. While, morpho-arrangement affects the distribution of unconfined groundwater, either horizontally or vertically, the relation between the groundwater availability and the citizen distribution or the form of the existing land use.

Geological structure will affect the direction of groundwater movement, the type and the potential of aquifer. Stratigraphy compiled by several rock layer will affect the type of the aquifer, the depth and the thickness of groundwater. The type and the age of rock will determine the groundwater quality. Besides, it will also affect the coefficient value of its aquifer permeability. Rock having small release (impermeable) will release water in small amount, so that the amount of water entering the aquifer is also a few. On the contrary, the permeable layer will give much water entering as the groundwater supply.

Groundwater movement in aquifer cases the happening of minerals dilution in the rock it passed, so that it will affect the change of groundwater chemical composition. The analysis of groundwater hydro-chemical type can explain important information about groundwater characteristic, its origin, and the chemical type of groundwater. Such a condition can be related to hydrological and geological environment in the space where the groundwater exist (sedimentation environment).

To find out and study the characteristic or the distribution of groundwater, it is used geomorphologic approach emphasizing the main study on the landform. Each landform unit can be used to arrange hydromorphology unit. Hydromorphology unit can be used as the evaluation and analysis base in planning and managing groundwater resource, its relation with primary water providence for drinking water.

\section{RESEARCH METHOD}

Survey method was applied in this research, systematic investigation comprising of explanation of description, classification, and mapping of hydrogmorphology unit. Survey approach unit used was geomorphology, emphasizing on the landform as the smallest analysis unit.

The method determining measurement point and sampling was stratified sampling based on the level of landform unit as the base of analysis, classification, and evaluation of unconfined groundwater characteristic in the research area. The data of groundwater physical characteristics as a result of measurement was analyzed and made into classification into 3 groups. They were low/shallow/slow, medium, and high/deep/fast.

The classification of depth of unconfined groundwater surface (water table) is:

(a) shallow groundwater class $(\mathrm{Dk})=<7$ meter;

(b) medium groundwater class(Ds) $=7$ 15 meter; 
(c) deep groundwater class (Dl) => 15 meter.

The classification of electrical conductivity (EC) of unconfined groundwater is:

(a) low EC class (ECr) $=<1000$ mmhos/ $\mathrm{cm}$ (fresh water);

(b) medium EC class (ECs) $=1000-2500$ $\mathrm{mmhos} / \mathrm{cm}$ (semi salty water);

(c) high EC class $(\mathrm{ECt})=>2500$ mmhos $/$ $\mathrm{cm}$ (brackish to salty water).

The result of groundwater analysis in laboratory in the scale of $\mathrm{mg} /$ liter (ppm) or meq/liter (epm) is matched with drinking water standard quality (Government Rule Number 20 on 1990). The class of groundwater quality used is:

(a) good groundwater quality (Ab) = Class A;

(b) medium groundwater quality (As) = Class B;

(c) poor groundwater quality (Ar) = outside Class A and B.

The hydro-chemical groundwater type was determined by the Square Piper Diagram, comprising of: type I (bicarbonate water), type II (semi-carbonate water), type III (evaporated water), type IV (sulfate water), type $\mathrm{V}$ (connate water), and type VI (seawater intrusion).

Aquifer permeability was tested using pumping test with the method of Slug Test (Shallow Dug Well Recovery Test), which then classified as follow:

(a) low permeability $(\mathrm{Kr})=<0.0002 \mathrm{~cm} /$ second $=<0.17 \mathrm{~m} /$ day;

(b) medium permeability $(\mathrm{Ks})=0.0002$ $0.0100 \mathrm{~cm} /$ second $=0.17-8.64 \mathrm{~m} /$ day;

(c) high permeability $(\mathrm{Kc})=>0.0100 \mathrm{~cm} /$ second $=>8.64 \mathrm{~m} /$ day.
All analyzed and classified measurement data is plotted in Landform Unit Map as analysis unit to Hydromorphology Map. This latter map was used as the base of the analysis direction or recommendation for the planning of unconfined groundwater use for drinking water to the people.

\section{RESEARCH RESULT AND DISCUS- SION}

\section{Landform Unit in the Research Area}

Based on the result of interpretation and analysis of remote sensing data, topographic map, and geological map, include the morphological parameters (slope), structure, process, and materials, which subsequently carried out field check, in fact, in the research area, it is composed of 13 landform units, as presented in Table 1.

\section{The Characteristic of Unconfined} Groundwater in the Research Area

Based on the result of field measurement and the database of previous research results, the condition of groundwater electric conductivity distribution, water table, and groundwater surface fluctuation in the research area in each landform unit, as can be seen in Table 2. Subsequently, based on the data above, it were made classification of electric conductivity value and its water table depth, as can be seen in Table 3. To find out its water quality, it was taken several samples in several landform units relatively have striking electric conductivity value. The result of laboratory test and the analysis of groundwater quality can be seen in Table 4. The data of laboratory test result subsequently was used as the analysis base and the determination of groundwater hydro-chemical type, whose classification can be seen in Table 5 . 
Table 1. Landform Units and Its Characteristic in the Research Area

\begin{tabular}{|c|c|c|c|c|c|}
\hline No & Landform & $\begin{array}{c}\text { Relief } \\
(\%)\end{array}$ & Structure & Process & Litology / Material \\
\hline 1. & $\begin{array}{l}\text { Volcanic Foot Plain } \\
\text { of Young Merapi (Al } \\
\text { F Mm) }\end{array}$ & $5-10$ & $\begin{array}{l}\text { Horizontal } \\
\text { follow the } \\
\text { slope pattern }\end{array}$ & $\begin{array}{l}\text { Sedimentation } \\
\text { of stream flow }\end{array}$ & $\begin{array}{l}\text { Pyroclastic materials } \\
\text { of Young Merapi } \\
\text { Volcanic }\end{array}$ \\
\hline 2. & $\begin{array}{l}\text { Fluvio Volcanic } \\
\text { Plain of Young } \\
\text { Merapi (Fl V Mm) }\end{array}$ & $0-8$ & $\begin{array}{l}\text { Horizontal } \\
\text { follow the } \\
\text { slope pattern }\end{array}$ & $\begin{array}{l}\text { Sedimentation } \\
\text { of stream flow }\end{array}$ & Alluvium materials \\
\hline 3. & $\begin{array}{l}\text { Swamp Alluvial Plain } \\
\text { (Al P Sw) }\end{array}$ & $<3$ & Horizontal & $\begin{array}{l}\text { Sedimentation } \\
\text { of swamp }\end{array}$ & Alluvium swamp \\
\hline 4. & $\begin{array}{l}\text { Undulating Alluvial } \\
\text { Plain (Al P Ud) }\end{array}$ & $3-8$ & Horizontal & $\begin{array}{l}\text { Sedimentation } \\
\text { of stream flow }\end{array}$ & Sandy clay \\
\hline 5. & Flood Plain (Al P St) & $3-5$ & Horizontal & $\begin{array}{l}\text { Sedimentation } \\
\text { of stream flow } \\
\text { and flood } \\
\text { regularly }\end{array}$ & Sandy clay \\
\hline 6. & $\begin{array}{l}\text { Alluvial Fan of } \\
\text { Baturagung Hill (Al } \\
\text { F Bt) }\end{array}$ & $3-8$ & $\begin{array}{l}\text { Horizontal } \\
\text { follow the } \\
\text { slope pattern }\end{array}$ & $\begin{array}{l}\text { Sedimentation } \\
\text { and deposition } \\
\text { of slope } \\
\text { material, and rill } \\
\text { erosion }\end{array}$ & $\begin{array}{l}\text { Coarse sandy clay, } \\
\text { gravel, and pebble of } \\
\text { physical weathering } \\
\text { of hilly bedrock }\end{array}$ \\
\hline 7. & $\begin{array}{l}\text { Foot Slope of } \\
\text { Baturgung Hill (Cd } \\
\text { Fs Bt) }\end{array}$ & $8-25$ & None & $\begin{array}{l}\text { Weathering, } \\
\text { mass movement, } \\
\text { and rill or valley } \\
\text { erosion }\end{array}$ & $\begin{array}{l}\text { Colluvium materials } \\
\text { of agglomerate, } \\
\text { breccia, tuff, and } \\
\text { sandstone }\end{array}$ \\
\hline 8. & $\begin{array}{l}\text { Baturagung } \\
\text { Structurally Hill (Sd } \\
\text { H Bt) }\end{array}$ & $25->45$ & $\begin{array}{l}\text { Step Faults } \\
\text { Hill }\end{array}$ & $\begin{array}{l}\text { Weathering, } \\
\text { mass movement, } \\
\text { and rill or valley } \\
\text { erosion }\end{array}$ & $\begin{array}{l}\text { Semilir dan } \\
\text { Nglanggran Beds: } \\
\text { agglomerate, breccia, } \\
\text { tuff, \& sandstone }\end{array}$ \\
\hline 9. & $\begin{array}{l}\text { Foot Slope of Bayat } \\
\text { Hill (Cd Fs BY) }\end{array}$ & $8-15$ & None & $\begin{array}{l}\text { Weathering, } \\
\text { mass movement, } \\
\text { and rill or valley } \\
\text { erosion }\end{array}$ & $\begin{array}{l}\text { Colluvium materials } \\
\text { of microdiorite, } \\
\text { numulits, skisa, and } \\
\text { phylite }\end{array}$ \\
\hline 10. & $\begin{array}{l}\text { Bayat Metamorphic } \\
\text { Structurally Hill } \\
\text { (Sd H Mf) }\end{array}$ & $25-45$ & Faulted Hill & $\begin{array}{l}\text { Weathering, } \\
\text { mass movement, } \\
\text { and rill or valley } \\
\text { erosion }\end{array}$ & $\begin{array}{l}\text { Metamorphic rocks } \\
\text { of skiss and phylite }\end{array}$ \\
\hline 11. & $\begin{array}{l}\text { Bayat Microdiorite } \\
\text { Denudational Hill } \\
\text { (Sd H Md) }\end{array}$ & $15-25$ & None & $\begin{array}{l}\text { Weathering and } \\
\text { rill or valley } \\
\text { erosion }\end{array}$ & $\begin{array}{l}\text { Intrusion rock of } \\
\text { microdiorite }\end{array}$ \\
\hline 12. & $\begin{array}{l}\text { Foot Slope of Bayat } \\
\text { Limestone Hill (Fs } \\
\text { K) }\end{array}$ & $8-15$ & None & $\begin{array}{l}\text { Weathering, } \\
\text { dilution, and rill } \\
\text { or valley erosion }\end{array}$ & $\begin{array}{l}\text { Colluvium materials } \\
\text { and dilution of } \\
\text { Foraminifera } \\
\text { limestone of } \\
\text { Wonosari Bed }\end{array}$ \\
\hline 13. & $\begin{array}{l}\text { Bayat Limestone Hill } \\
\text { (K H Fm) }\end{array}$ & $15-25$ & None & $\begin{array}{l}\text { Weathering, } \\
\text { dilution, and rill } \\
\text { erosion }\end{array}$ & $\begin{array}{l}\text { Foraminifera } \\
\text { limestone of } \\
\text { Wonosari Bed }\end{array}$ \\
\hline
\end{tabular}

Sources: Analysis of Topographic Map, Geologic Map, Remote Sensing Data Interpretation

Widiyanto and Jamulya (1993); Langgeng and Widyastuti (1998); Field Survey (2004) 
Table 2. Characteristic of the Unconfined Groundwater in the Research Area

\begin{tabular}{|c|c|c|c|c|c|c|}
\hline Sample & Location & $\begin{array}{l}\text { Land- } \\
\text { form }\end{array}$ & $\begin{array}{c}\mathrm{EC} \\
(\mu \mathrm{m} / \\
\mathrm{cm})\end{array}$ & $\begin{array}{l}\text { Water } \\
\text { Table } \\
\text { Depth } \\
\text { (m) }\end{array}$ & $\begin{array}{l}\text { Fluctu- } \\
\text { ation } \\
\text { (m) }\end{array}$ & Groundwater Condition \\
\hline $\begin{array}{l}\text { A. } 1 \\
\text { A. } 2\end{array}$ & $\begin{array}{l}\text { Brajan, Prb } \\
\text { Wonoboyo, Prb }\end{array}$ & $\begin{array}{l}\mathrm{AL} \mathrm{F} \\
\mathrm{Mm}\end{array}$ & $\begin{array}{l}560 \\
623\end{array}$ & $\begin{array}{l}6 \\
4\end{array}$ & $\begin{array}{l}>4 \\
>4\end{array}$ & $\begin{array}{l}\text { Clear, fresh, no smell, sometimes dried in } \\
\text { the dry season, materials are coarse sand } \\
\text { and gravel. }\end{array}$ \\
\hline $\begin{array}{l}\text { A.3 } \\
\text { A. } 4 \\
\text { A. } 5 \\
\text { A.6 } \\
\text { A. } \\
\text { A. } 8 \\
\text { A. } 9 \\
\text { A.10 } \\
\text { A.11 } \\
\text { A.12 }\end{array}$ & $\begin{array}{l}\text { Geneng, Prb } \\
\text { Muruh, Gtw } \\
\text { Mlese, Gtw } \\
\text { Towangsan, Gtw } \\
\text { Krandon, Wedi } \\
\text { Pesu, Wedi } \\
\text { Canan, Wedi } \\
\text { Pasung, Wedi } \\
\text { Kaporan, Wedi } \\
\text { Jambakan, Byt }\end{array}$ & $\begin{array}{l}\mathrm{Fl} \mathrm{V} \\
\mathrm{Mm}\end{array}$ & $\begin{array}{l}542 \\
540 \\
520 \\
610 \\
602 \\
515 \\
530 \\
524 \\
540 \\
2810\end{array}$ & $\begin{array}{c}3 \\
2 \\
1 \\
3 \\
4 \\
1 \\
2 \\
1.5 \\
1.5 \\
2-4\end{array}$ & $\begin{array}{l}2-3 \\
2-3 \\
2-3 \\
2-3 \\
\pm 3 \\
2-3 \\
2-3 \\
2-3 \\
2-3 \\
1-2\end{array}$ & $\begin{array}{l}\text { Clear, fresh, no smell, in the several places } \\
\text { on the northern area sometimes dried in the } \\
\text { dry season, materials sandy clay. In Bayat } \\
\text { (sample A.12): high on EC value }(>2500 \\
\mu \text { mhos/cm), brackish and rather smell. }\end{array}$ \\
\hline $\begin{array}{l}\text { A.13 } \\
\text { A.14 } \\
\text { A.15 } \\
\text { A.16 } \\
\text { A.17 }\end{array}$ & $\begin{array}{l}\text { Katekan, Gtw } \\
\text { Kerten, Gtw } \\
\text { Ngandong, Gtw } \\
\text { Lebak, Byt } \\
\text { Bugel, Byt }\end{array}$ & $\begin{array}{l}\mathrm{Al} \mathrm{P} \\
\mathrm{Sw}_{\mathrm{W}}\end{array}$ & $\begin{array}{c}720 \\
680 \\
684 \\
2515 \\
4915\end{array}$ & $\begin{array}{c}1 \\
2-5 \\
2-3 \\
3 \\
1\end{array}$ & $\begin{array}{l}3-4 \\
>3 \\
>3 \\
2-3 \\
2-3\end{array}$ & $\begin{array}{l}\text { Generally clear, in the several places } \\
\text { groundwater is rather muddy, smell like } \\
\text { mud, in the western area sometimes dried in } \\
\text { the long dry season, and in Bayat generally } \\
\text { brackish. }\end{array}$ \\
\hline $\begin{array}{l}\text { A. } 18 \\
\text { A. } 19 \\
\text { A. } 20 \\
\text { A. } 21 \\
\text { A. } 22 \\
\text { A. } 23 \\
\text { A. } 24 \\
\end{array}$ & $\begin{array}{l}\text { Soko, Gtw } \\
\text { Teluk, Gtw } \\
\text { Jalek, Byt } \\
\text { Serut, Byt } \\
\text { Wiro, Byt } \\
\text { Jonggrangan, Byt } \\
\text { Talang, Byt } \\
\end{array}$ & $\begin{array}{l}\text { Al P } \\
\text { St }\end{array}$ & $\begin{array}{c}872 \\
720 \\
1258 \\
1940 \\
1760 \\
1526 \\
1280 \\
\end{array}$ & \begin{tabular}{|c|}
$1.5-2$ \\
$2-4$ \\
$3-4$ \\
7 \\
1 \\
6 \\
2 \\
\end{tabular} & $\begin{array}{l}>3 \\
>5 \\
>3 \\
>3 \\
2-3 \\
>3 \\
>2\end{array}$ & $\begin{array}{l}\text { Generally clear, fresh in the western area, } \\
\text { rather brackish to brackish in the eastern } \\
\text { area (Bayat), rather smell and muddy in } \\
\text { rainy, in the several places sometimes dried } \\
\text { in the dry season, material is sandy clay. }\end{array}$ \\
\hline $\begin{array}{l}\text { A.25 } \\
\text { A.26 } \\
\text { A. } 27 \\
\end{array}$ & $\begin{array}{l}\text { Ngerangan, Byt } \\
\text { Banyuripan, Byt } \\
\text { Beluk, Byt }\end{array}$ & $\begin{array}{l}\mathrm{Al} \mathrm{P} \\
\mathrm{Ud}\end{array}$ & $\begin{array}{l}1060 \\
1045 \\
1125 \\
\end{array}$ & $\begin{array}{l}9 \\
5 \\
5\end{array}$ & $\begin{array}{l}3-4 \\
>3 \\
2-3\end{array}$ & $\begin{array}{l}\text { Generally clear and fresh, no smell, } \\
\text { sometimes dried in the dry season, materials } \\
\text { are sandy clay and sand. }\end{array}$ \\
\hline $\begin{array}{l}\text { A.28 } \\
\text { A.29 }\end{array}$ & $\begin{array}{l}\text { Bogem, Byt } \\
\text { Jarum, Byt }\end{array}$ & $\begin{array}{l}\mathrm{Al} \mathrm{F} \\
\mathrm{Bt}\end{array}$ & $\begin{array}{l}620 \\
687\end{array}$ & $\begin{array}{c}13 \\
8\end{array}$ & $\begin{array}{l}3-5 \\
3-5\end{array}$ & $\begin{array}{l}\text { Generally clear and fresh, no smell, } \\
\text { sometimes dried in the dry season, materials } \\
\text { are sand and gravel. }\end{array}$ \\
\hline A.30 & Dukuh, Bayat & $\begin{array}{l}\mathrm{Cd} \mathrm{Fs} \\
\mathrm{Bt}\end{array}$ & 760 & 5 & $2-3$ & $\begin{array}{l}\text { Generally clear and fresh, no smell, } \\
\text { sometimes dried in the dry season, materials } \\
\text { are breccia and agglomerate. }\end{array}$ \\
\hline $\begin{array}{l}\text { A.31 } \\
\text { A.32 } \\
\text { A.33 } \\
\text { A.34 } \\
\text { A.35 } \\
\text { A.36 } \\
\end{array}$ & $\begin{array}{l}\text { Jerukan, Byt } \\
\text { Tegalsari, Byt } \\
\text { Jotangan, Byt } \\
\text { Gunungbang, Byt } \\
\text { Melikan, Wedi } \\
\text { Krakitan, Byt } \\
\end{array}$ & $\begin{array}{l}\text { Cd Fs } \\
\text { By }\end{array}$ & $\begin{array}{c}1020 \\
773 \\
891 \\
1030 \\
630 \\
580 \\
\end{array}$ & $\begin{array}{c}4 \\
6 \\
12 \\
4.5 \\
6 \\
10 \\
\end{array}$ & $\begin{array}{l}>2 \\
>3 \\
>3 \\
>2 \\
>2 \\
>3\end{array}$ & $\begin{array}{l}\text { Generally clear and fresh, no smell, } \\
\text { sometimes dried in the dry season, materials } \\
\text { is colluvium of numulite, skiss and phylite. }\end{array}$ \\
\hline A.37 & G. Pendul, Byt & $\begin{array}{l}\mathrm{Sd} \mathrm{H} \\
\mathrm{Md}\end{array}$ & 735 & 7.5 & $>3$ & $\begin{array}{l}\text { Generally clear and fresh, no smell, } \\
\text { sometimes dried in the dry season, materials } \\
\text { is colluvium of microdiorite. }\end{array}$ \\
\hline $\begin{array}{l}\text { A.38 } \\
\text { A.39 }\end{array}$ & $\begin{array}{l}\text { G. Konang, Byt } \\
\text { G. Kebo, Byt }\end{array}$ & $\begin{array}{l}\mathrm{Sd} \mathrm{H} \\
\mathrm{Mf}\end{array}$ & $\begin{array}{c}1060 \\
485\end{array}$ & $\begin{array}{r}>7 \\
10.5\end{array}$ & $\begin{array}{l}>3 \\
>3\end{array}$ & $\begin{array}{l}\text { Generally clear and fresh, no smell, } \\
\text { sometimes dried in the dry season, materials } \\
\text { is colluvium of skiss and phylite. }\end{array}$ \\
\hline A. 40 & Ngasem, Byt & Fs $\mathrm{K}$ & 537 & 11.5 & $>3$ & $\begin{array}{l}\text { Generally clear and fresh, no smell, } \\
\text { sometimes dried in the dry season, materials } \\
\text { is colluvium of limestone. }\end{array}$ \\
\hline $\begin{array}{l}\text { A.41 } \\
\text { A.42 }\end{array}$ & $\begin{array}{l}\text { G. Jeto, Byt } \\
\text { G. Temas, Byt }\end{array}$ & $\begin{array}{l}\mathrm{K} \mathrm{H} \\
\mathrm{Fm}\end{array}$ & $\begin{array}{l}714 \\
761\end{array}$ & $\begin{array}{l}5.5 \\
9.5\end{array}$ & $\begin{array}{l}2-3 \\
>4\end{array}$ & $\begin{array}{l}\text { Generally clear and fresh, no smell, } \\
\text { sometimes dried in the dry season, materials } \\
\text { is foraminifera limestone. }\end{array}$ \\
\hline
\end{tabular}

Sources: Langgeng and Widyastuti (1998); Field Survey (2004) 
Table 3. Classification of Electric Conductivity and Depth of Water Table in the Research Area

\begin{tabular}{|c|c|c|c|c|c|c|}
\hline \multirow{2}{*}{ Sample } & \multirow{2}{*}{ Landform } & \multicolumn{2}{|c|}{$\mathrm{EC}(\mu \mathrm{m} / \mathrm{cm})$} & \multicolumn{2}{|c|}{ Water Table (m) } & \multirow{2}{*}{ Note } \\
\hline & & Value & Class & Value & Class & \\
\hline $\begin{array}{l}\text { A. } 1 \\
\text { A. } 2\end{array}$ & $\begin{array}{l}\text { AL F } \\
\mathrm{Mm}\end{array}$ & $\begin{array}{l}560 \\
623\end{array}$ & $\begin{array}{l}\text { Low } \\
\text { Low }\end{array}$ & $\begin{array}{l}6 \\
4\end{array}$ & $\begin{array}{l}\text { Shallow } \\
\text { Shallow }\end{array}$ & $\begin{array}{l}\text { Low on EC (fresh groundwater), shallow water } \\
\text { table, but there is handicap on fluctuation }(>4 \\
\text { meter). }\end{array}$ \\
\hline $\begin{array}{l}\text { A.3 } \\
\text { A. } 4 \\
\text { A. } 5 \\
\text { A. } 6 \\
\text { A. } 7 \\
\text { A. } 8 \\
\text { A. } 9 \\
\text { A. } 10 \\
\text { A. } 11 \\
\text { A.12 } \\
\end{array}$ & Fl V Mm & $\begin{array}{c}542 \\
540 \\
520 \\
610 \\
602 \\
515 \\
530 \\
524 \\
540 \\
\mathbf{2 8 1 0} \\
\end{array}$ & $\begin{array}{l}\text { Low } \\
\text { Low } \\
\text { Low } \\
\text { Low } \\
\text { Low } \\
\text { Low } \\
\text { Low } \\
\text { Low } \\
\text { Low } \\
\text { High } \\
\end{array}$ & $\begin{array}{c}3 \\
2 \\
1 \\
3 \\
4 \\
1 \\
2 \\
1.5 \\
1.5 \\
2-4 \\
\end{array}$ & $\begin{array}{l}\text { Shallow } \\
\text { Shallow } \\
\text { Shallow } \\
\text { Shallow } \\
\text { Shallow } \\
\text { Shallow } \\
\text { Shallow } \\
\text { Shallow } \\
\text { Shallow } \\
\text { Shallow } \\
\end{array}$ & $\begin{array}{l}\text { Generally low on EC }(<1000 \mu \mathrm{mhos} / \mathrm{cm}) \text {, } \\
\text { fresh and shallow groundwater. } \\
\text { High EC (brackish) is just met locally in Bayat } \\
\text { (maybe related with the genesis of the region, } \\
\text { paleo lithoral zone). }\end{array}$ \\
\hline $\begin{array}{l}\text { A.13 } \\
\text { A.14 } \\
\text { A.15 } \\
\text { A.16 } \\
\text { A.17 }\end{array}$ & $\mathrm{Al} \mathrm{P} \mathrm{Sw}$ & $\begin{array}{r}720 \\
680 \\
684 \\
2515 \\
4915\end{array}$ & $\begin{array}{l}\text { Low } \\
\text { Low } \\
\text { Low } \\
\text { High } \\
\text { High }\end{array}$ & $\begin{array}{c}1 \\
2-5 \\
2-3 \\
3 \\
1\end{array}$ & $\begin{array}{l}\text { Shallow } \\
\text { Shallow } \\
\text { Shallow } \\
\text { Shallow } \\
\text { Shallow }\end{array}$ & $\begin{array}{l}\text { In the western area, generally low on EC and } \\
\text { shallow groundwater. } \\
\text { Locally in Bayat, high EC (brackish to saline), } \\
\text { especially around the Jombor swamp. }\end{array}$ \\
\hline $\begin{array}{l}\text { A.18 } \\
\text { A.19 } \\
\text { A.20 } \\
\text { A.21 } \\
\text { A.22 } \\
\text { A. } 23 \\
\text { A. } 24\end{array}$ & $\mathrm{Al} \mathrm{P} \mathrm{St}$ & $\begin{array}{c}872 \\
720 \\
1258 \\
1940 \\
1760 \\
1526 \\
1280 \\
\end{array}$ & $\begin{array}{l}\text { Low } \\
\text { Low } \\
\text { Medium } \\
\text { Medium } \\
\text { Medium } \\
\text { Medium } \\
\text { Medium }\end{array}$ & $\begin{array}{c}1.5-2 \\
2-4 \\
3-4 \\
7 \\
1 \\
6 \\
2 \\
\end{array}$ & $\begin{array}{l}\text { Shallow } \\
\text { Shallow } \\
\text { Shallow } \\
\text { Shallow } \\
\text { Shallow } \\
\text { Shallow } \\
\text { Shallow }\end{array}$ & $\begin{array}{l}\text { In the western area low on EC, in the eastern } \\
\text { area medium on EC, generally shallow } \\
\text { groundwater, and in the western area high } \\
\text { fluctuation. }\end{array}$ \\
\hline $\begin{array}{l}\text { A.25 } \\
\text { A.26 } \\
\text { A. } 27\end{array}$ & $\mathrm{Al}$ P Ud & $\begin{array}{l}1060 \\
1045 \\
1125 \\
\end{array}$ & $\begin{array}{l}\text { Medium } \\
\text { Medium } \\
\text { Medium }\end{array}$ & $\begin{array}{l}9 \\
5 \\
5 \\
\end{array}$ & $\begin{array}{l}\text { Medium } \\
\text { Shallow } \\
\text { Shallow }\end{array}$ & $\begin{array}{l}\text { Medium on EC, shallow to medium water table, } \\
\text { and sometimes dried in the dry season. }\end{array}$ \\
\hline $\begin{array}{l}\text { A.28 } \\
\text { A.29 }\end{array}$ & $\mathrm{Al} \mathrm{F} \mathrm{Bt}$ & $\begin{array}{l}620 \\
687 \\
\end{array}$ & $\begin{array}{l}\text { Low } \\
\text { Low }\end{array}$ & $\begin{array}{c}13 \\
8 \\
\end{array}$ & $\begin{array}{l}\text { Medium } \\
\text { Medium }\end{array}$ & $\begin{array}{l}\text { Low on EC, medium on water table, and high } \\
\text { fluctuation. }\end{array}$ \\
\hline A.30 & $\mathrm{Cd} \mathrm{Fs} \mathrm{Bt}$ & 760 & Low & 5 & Shallow & $\begin{array}{l}\text { Low on EC, shallow water table, and medium } \\
\text { on fluctuation. }\end{array}$ \\
\hline $\begin{array}{l}\text { A.31 } \\
\text { A.32 } \\
\text { A.33 } \\
\text { A.34 } \\
\text { A.35 } \\
\text { A.36 } \\
\end{array}$ & Cd Fs By & $\begin{array}{c}1020 \\
773 \\
891 \\
1030 \\
630 \\
580 \\
\end{array}$ & $\begin{array}{l}\text { Medium } \\
\text { Low } \\
\text { Low } \\
\text { Medium } \\
\text { Low } \\
\text { Low } \\
\end{array}$ & $\begin{array}{c}4 \\
6 \\
12 \\
4.5 \\
6 \\
10 \\
\end{array}$ & $\begin{array}{l}\text { Shallow } \\
\text { Shallow } \\
\text { Medium } \\
\text { Shallow } \\
\text { Shallow } \\
\text { Medium }\end{array}$ & $\begin{array}{l}\text { Low to medium on EC, shallow to medium on } \\
\text { water table, and sometimes dried in the dry } \\
\text { season. }\end{array}$ \\
\hline A. 37 & Sd H Md & 735 & Low & 7.5 & Medium & $\begin{array}{l}\text { Low on EC, medium on water table, and } \\
\text { medium on fluctuation. }\end{array}$ \\
\hline $\begin{array}{l}\text { A.38 } \\
\text { A.39 }\end{array}$ & Sd H Mf & $\begin{array}{c}1060 \\
485\end{array}$ & $\begin{array}{l}\text { Medium } \\
\text { Low }\end{array}$ & $\begin{array}{r}>7 \\
10.5\end{array}$ & $\begin{array}{l}\text { Medium } \\
\text { Medium }\end{array}$ & $\begin{array}{l}\text { Low to medium on EC, medium on water } \\
\text { table, and medium on fluctuation. }\end{array}$ \\
\hline A. 40 & Fs K & 537 & Low & 11.5 & Medium & $\begin{array}{l}\text { Low on EC, medium on water table, and } \\
\text { medium on fluctuation, sometimes dried in the } \\
\text { dry season. }\end{array}$ \\
\hline $\begin{array}{l}\text { A. } 41 \\
\text { A. } 42\end{array}$ & K H Fm & $\begin{array}{l}714 \\
761\end{array}$ & $\begin{array}{l}\text { Low } \\
\text { Low }\end{array}$ & $\begin{array}{l}8.5 \\
9.5\end{array}$ & $\begin{array}{l}\text { Medium } \\
\text { Medium }\end{array}$ & $\begin{array}{l}\text { Low on EC, medium on water table, and high } \\
\text { on fluctuation, sometimes dried in the dry } \\
\text { season. }\end{array}$ \\
\hline
\end{tabular}

Sources: Data Analysis: Langgeng and Widyastuti (1998), and Field Survey (2004) 
Table 4. Chemical Analysis and Classification of Unconfined Groundwater Quality in the Research Area

\begin{tabular}{|c|c|c|c|c|c|c|c|c|c|}
\hline \multirow{2}{*}{ Parameters } & \multicolumn{9}{|c|}{ Groundwater Samples } \\
\hline & A.17 & A. 20 & A. 25 & A. 29 & A.31 & A.37 & A. 38 & A. 40 & A.42 \\
\hline Landform & Al P Sw & $\mathrm{Al} \mathrm{P} \mathrm{St}$ & $\mathrm{Al}$ P Ud & $\mathrm{Al} \mathrm{F} \mathrm{Bt}$ & Cd Fs By & $\mathrm{Sd} \mathrm{H} \mathrm{Md}$ & Sd H Mf & Fs $\mathrm{K}$ & K H Fm \\
\hline $\mathrm{pH}$ & 6,91 & 7,43 & 7,20 & 7,30 & 7,10 & 6,97 & 7,00 & 7,19 & 6,81 \\
\hline Temperature $\left({ }^{\circ} \mathrm{C}\right)$ & 27,2 & 27,1 & 26,5 & 26,8 & 26,7 & 26,5 & 26,7 & 26,9 & 26,7 \\
\hline $\mathrm{EC}(\mu \mathrm{mhos} / \mathrm{cm})$ & 4.915 & 1.258 & 1.125 & 687 & 685 & 435 & 1.060 & 537 & 761 \\
\hline Turbidity (NTU) & 1,20 & 1,90 & 1,60 & 2,00 & 1,40 & 1,45 & 1,62 & 1,80 & 0,95 \\
\hline $\begin{array}{l}\text { Physical Condition: } \\
\text { - Colour } \\
\text { - Taste } \\
\text { - Smell }\end{array}$ & $\begin{array}{l}\text { Clear } \\
\text { Saline } \\
\text { Rather }\end{array}$ & $\begin{array}{l}\text { Clear } \\
\text { Brackish } \\
\text { Rather }\end{array}$ & $\begin{array}{l}\text { Muddy } \\
\text { Brackish } \\
\text { None }\end{array}$ & $\begin{array}{l}\text { Clear } \\
\text { Fresh } \\
\text { None }\end{array}$ & $\begin{array}{l}\text { Clear } \\
\text { Fresh } \\
\text { None }\end{array}$ & $\begin{array}{l}\text { Clear } \\
\text { Fresh } \\
\text { None }\end{array}$ & $\begin{array}{l}\text { Clear } \\
\text { Fresh } \\
\text { None }\end{array}$ & $\begin{array}{l}\text { Clear } \\
\text { Fresh } \\
\text { None }\end{array}$ & $\begin{array}{l}\text { Clear } \\
\text { Fresh } \\
\text { None }\end{array}$ \\
\hline $\begin{array}{l}\text { Ion Concentration: } \\
\mathrm{Na}^{+} \\
\mathrm{K}^{+} \\
\mathrm{Ca}^{2+} \\
\mathrm{CaCO}_{3} \\
\mathrm{Mg}^{2+} \\
\mathrm{Fe}^{3+} \\
\mathrm{Cl}^{-} \\
\mathrm{HCO}_{3} \\
\mathrm{CO}_{3}= \\
\mathrm{SO}_{4}= \\
\mathrm{Mn}^{2+} \\
\mathrm{NO}_{3}^{-} \\
\mathrm{NH}_{3} \\
\end{array}$ & \begin{tabular}{|}
333,00 \\
20,60 \\
769,00 \\
238,00 \\
113,00 \\
0,00 \\
1488,00 \\
320,00 \\
0,00 \\
700,00 \\
0,00 \\
295,00 \\
266,00
\end{tabular} & $\begin{array}{r}90,90 \\
12,40 \\
172,00 \\
600,00 \\
41,10 \\
0,00 \\
82,90 \\
240,00 \\
0,00 \\
224,00 \\
0,00 \\
46,00 \\
0,00\end{array}$ & $\begin{array}{r}46,20 \\
1,50 \\
86,20 \\
692,00 \\
116,00 \\
0,00 \\
34,10 \\
504,00 \\
0,00 \\
56,00 \\
0,00 \\
45,00 \\
0,78\end{array}$ & $\begin{array}{r}47,00 \\
2,60 \\
91,10 \\
289,00 \\
15,10 \\
0,00 \\
19,50 \\
179,00 \\
0,00 \\
38,00 \\
0,00 \\
18,00 \\
0,69\end{array}$ & $\begin{array}{r}45,10 \\
1,40 \\
108,00 \\
295,00 \\
6,20 \\
0,00 \\
10,20 \\
390,00 \\
0,00 \\
23,00 \\
0,00 \\
20,10 \\
1,52\end{array}$ & $\begin{array}{r}43,20 \\
1,60 \\
101,00 \\
289,00 \\
9,10 \\
0,00 \\
9,80 \\
394,00 \\
0,00 \\
18,00 \\
0,00 \\
19,20 \\
1,44\end{array}$ & $\begin{array}{r}105,00 \\
2,80 \\
98,40 \\
262,00 \\
4,00 \\
0,00 \\
16,60 \\
430,00 \\
0,00 \\
36,00 \\
0,00 \\
18,70 \\
5,15\end{array}$ & $\begin{array}{r}18,90 \\
1,20 \\
73,80 \\
209,00 \\
6,10 \\
0,00 \\
11,70 \\
195,00 \\
0,00 \\
12,00 \\
0,00 \\
18,00 \\
0,00\end{array}$ & $\begin{array}{r}15,20 \\
0,70 \\
51,70 \\
289,00 \\
39,00 \\
0,00 \\
11,70 \\
365,00 \\
0,00 \\
32,00 \\
0,00 \\
18,40 \\
1,25\end{array}$ \\
\hline Quality & Good & Medium & Medium & Good & Good & Good & Good & Good & Good \\
\hline Limiting Factors & \begin{tabular}{|c|}
$\mathrm{Cl}, \mathrm{Ca}$, \\
$\mathrm{SO} 4$
\end{tabular} & $\mathrm{CaCO} 3$ & $\begin{array}{c}\mathrm{CaCO} 3 \\
\mathrm{NH} 3\end{array}$ & NH3 & NH3 & $\mathrm{NH} 3$ & $\mathrm{NH} 3$ & - & NH3 \\
\hline
\end{tabular}

Sources: Data Analysis: Langgeng and Widyastuti (1998), and Field Survey (2004)

Table 5. Analysis and Classification of the Hydro-chemical Type of Unconfined Groundwater in the Research Area

\begin{tabular}{|c|c|c|c|c|c|c|c|}
\hline \multirow{2}{*}{ Sample } & \multirow{2}{*}{ Landform } & \multirow{2}{*}{$\begin{array}{c}\text { EC } \\
(\mu \mathrm{mhos} / \\
\mathrm{cm})\end{array}$} & \multicolumn{4}{|c|}{ Cation Concentration (epm) } & \multirow{2}{*}{$\begin{array}{l}\text { Cation Total } \\
\quad(\text { epm) }\end{array}$} \\
\hline & & & $\mathrm{Na}$ & $\mathbf{K}$ & $\mathrm{Ca}$ & $\mathbf{M g}$ & \\
\hline A.17 & $\mathrm{Al} \mathrm{P} \mathrm{Sw}$ & 4915 & 14.50 & 0.53 & 38.39 & 9.31 & 62.73 \\
\hline A. 20 & $\mathrm{Al}$ P St & 1258 & 3.96 & 0.32 & 8.60 & 3.40 & 16.28 \\
\hline A. 25 & $\mathrm{Al} \mathrm{P} \mathrm{Ud}$ & 1125 & 4.58 & 0.08 & 4.89 & 0.32 & 9.86 \\
\hline A.29 & $\mathrm{Al} \mathrm{F} \mathrm{Bt}$ & 687 & 2.04 & 0.07 & 4.56 & 1.24 & 7.91 \\
\hline A.31 & Cd Fs By & 685 & 1.96 & 0.04 & 5.39 & 0.51 & 7.90 \\
\hline A.37 & Sd H Md & 735 & 1.88 & 0.04 & 5.04 & 0.75 & 7.71 \\
\hline A.38 & Sd H Mf & 1060 & 4.57 & 0.07 & 4.91 & 0.33 & 9.88 \\
\hline A. 40 & Fs K & 537 & 0.82 & 0.03 & 3.69 & 0.50 & 5.04 \\
\hline A.42 & K H Fm & 761 & 0.66 & 0.02 & 2.58 & 3.21 & 6.47 \\
\hline
\end{tabular}




\begin{tabular}{|c|l|c|c|c|c|c|c|}
\hline \multirow{2}{*}{ Sample } & \multirow{2}{*}{ Landform } & \multicolumn{5}{|c|}{ Anion Concentration (epm) } & Anion Total \\
\cline { 3 - 6 } & & $\mathbf{C l}$ & $\mathbf{S O}_{4}$ & $\mathbf{H C O}_{3}$ & $\mathbf{C O}_{3}$ & $\begin{array}{c}\text { Hidrochemical } \\
\text { Type }\end{array}$ \\
\hline A.17 & Al P Sw & 41.97 & 14.56 & 34.04 & 0 & 90.57 & III \\
\hline A.20 & Al P St & 2.34 & 4.66 & 25.53 & 0 & 32.53 & Va \\
\hline A.25 & Al P Ud & 0.49 & 0.73 & 45.72 & 0 & 46.98 & Va \\
\hline A.29 & Al F Bt & 0.55 & 0.80 & 19.07 & 0 & 20.42 & Va \\
\hline A.31 & Cd Fs By & 0.29 & 0.48 & 41.49 & 0 & 42.26 & Va \\
\hline A.37 & Sd H Md & 0.28 & 0.36 & 41.88 & 0 & 42.54 & Va \\
\hline A.38 & Sd H Mf & 0.47 & 0.75 & 45.75 & 0 & 46.97 & Va \\
\hline A.40 & Fs K & 0.33 & 0.24 & 20.77 & 0 & 21.34 & I \\
\hline A.42 & K H Fm & 0.33 & 0.67 & 38.81 & 0 & 39.81 & I \\
\hline
\end{tabular}

Sources: Data Analysis of Laboratory Test (2004)

Based on the result of groundwater hydro-chemical type testing in the research area, in fact there were 3 groundwater types, type I (bicarbonate water), type III (evaporated water) and type $\mathrm{Va}$ (initiation process of connate water).

(a) Type I hydro-chemical is bicarbonate water from calcium and magnesium. This group comprised of sample A.40 and A.42, in which both of them were parts of Foraminifera Limestone Hill unit in Bayat. This groundwater had high characteristic of $\mathrm{Ca}+\mathrm{Mg}$ and $\mathrm{HCO}, \mathrm{Na}+\mathrm{K}$ content low-medium, diluted compact substance and $\mathrm{pH}$ was relatively low. This groundwater is tasteless and has good quality. It can be used as drinking water. This type of groundwater is also met in Fluvio Volcanic Plain of Young Merapi unit (except Bayat), Flood Plain unit (except Bayat), Alluvial Fan of Baturagung Hill unit, and several places in the Baturagung Structurally Hill unit. This is supported by the physical characteristic and its low of $\mathrm{EC}$ value.

(b) Type III hydro-chemcal only comprised of sample A.17 and there were also possibly several samples having rela- tively high EC (> $2500 \mathrm{mmhos} / \mathrm{cm}$ ). This groundwater is included in evaporate water, generally come from shallow groundwater, high SO content, high $\mathrm{Ca}+\mathrm{Mg}$, low $\mathrm{Na}+\mathrm{K}$ and $\mathrm{HCO}$. The groundwater is brackish to salty, even sometimes stink. High SO content mostly over the maximum ${ }^{4}$ limit recommended, even sometimes over the maximum limit allowed. Low quality of groundwater generally comes from swamp sedimentation in alluvial plain. Such a condition is clearly met in Alluvial Swamp Plain unit (in Bayat), associated with sedimentation environment of ancient sea activities residual in Bayat (Pre-Tertiary era). This groundwater is sulfate or evaporated water, as a result of sedimentation process effect in limestone sedimentation resulting from salty water. High content of SO and $\mathrm{Cl}$ causes the groundwater changed into hardness and having low quality, in appropriate for drinking water.

(c) Other landform units are generally included in Va hydro-chemical type. Most of this group exists in the research area. The groundwater is tasteless groundwater with relatively low on $\mathrm{Cl}$ content. This group is marked by the beginning 
Table 6. Classification of the Aquifer Permeability in the Research Area

\begin{tabular}{|c|c|c|c|c|c|}
\hline Sample & Location & $\begin{array}{l}\text { Landfor } \\
\text { m }\end{array}$ & Materials / Litology & K (m/day) & Class \\
\hline$*)$ & - & $\mathrm{Al} \mathrm{F} \mathrm{Mm}$ & Coarse sand and gravel & $44,92-449,82$ & High \\
\hline P.1 & Ngerangan, Byt & $\mathrm{Fl} \mathrm{V} \mathrm{Mm}$ & Sandy clay & 1,35 & Medium \\
\hline $\begin{array}{c}\text { P.2 } \\
*)\end{array}$ & $\begin{array}{l}\text { Krakitan, Bayat } \\
\text { Gantiwarno }\end{array}$ & $\mathrm{Al} \mathrm{P} \mathrm{Sw}$ & Alluvium & $\begin{array}{l}0,12 \\
2,49\end{array}$ & $\begin{array}{l}\text { Low } \\
\text { Medium }\end{array}$ \\
\hline P.3 & Dukuh, Bayat & $\mathrm{Al} \mathrm{P} \mathrm{Ud}$ & Sandy clay & 0.42 & Medium \\
\hline P.4 & Bogem, Bayat & $\mathrm{Al} \mathrm{F} \mathrm{Bt}$ & Sand and gravel & 2,05 & Medium \\
\hline P.5 & Konang, Bayat & $\mathrm{Al} \mathrm{P} \mathrm{St}$ & Sandy clay & 0,07 & Low \\
\hline$*)$ & - & $\mathrm{Cd} \mathrm{Fs} \mathrm{Bt}$ & $\begin{array}{l}\text { Colluvioum: breccia, } \\
\text { agglomerate, and tuff }\end{array}$ & $0,01-449,28$ & Low to High \\
\hline$*)$ & - & $\mathrm{Sd} \mathrm{H} \mathrm{Bt}$ & Breccia, agglomerate, and tuff & 0,01 & Low \\
\hline P.6 & Konang, Byt & $\mathrm{Sd} \mathrm{H} \mathrm{Mf}$ & Skiss and phylite & 0,97 & Medium \\
\hline $\begin{array}{l}\text { P.7 } \\
\text { P.8 }\end{array}$ & $\begin{array}{l}\text { Jerukan, Bayat } \\
\text { Krikilan, Bayat }\end{array}$ & Cd Fs By & $\begin{array}{l}\text { Colluvium: microdiorite } \\
\text { Colluvium: skiss and phylite }\end{array}$ & $\begin{array}{l}3,34 \\
0,85\end{array}$ & $\begin{array}{l}\text { Medium } \\
\text { Medium }\end{array}$ \\
\hline P.9 & Temas, Bayat & K H Fm & Foraminifera limestone & 13,82 & High \\
\hline P.10 & Batilan, Bayat & Fs $\mathrm{K}$ & Colluvium: limestone & 1,2 & Medium \\
\hline
\end{tabular}

Sources: Data Analysis: Santosa (1995), and *) Todd (1980)

of cation exchange and the change to connate water. The quality of groundwater is still good and can be used for drinking water, but has to be careful because there is a possibility that cation exchange will continue into salty connate water.

The result data of pumping test in several landform units is analyzed to yield aquifer permeability value data in each compounding material, whose classification can be seen in Table 6. Based on this data, in fact, in the research field, there is also variation of coefficient classification of aquifer permeability, starting from slow to high permeability.

(a) High aquifer permeability coefficient is met in Volcanic Foot Plain of Young Merapi unit of 44,92 to $449,28 \mathrm{~m} /$ day, composed of hard sand materials and gravel, and in Bayat Limestone Hill unit of 13,824 m/day, composed of foraminifera limestone. The high level of aquifer permeability in both units is caused of its rock characteristic, which relatively has much big pores and many secondary cracks in the limestone, which enables better groundwater supply. The aquifer is able to catch, store, and distribute the water well and in large amount.

(b) Slow aquifer permeability coefficient is met in Swamp Alluvial Plain unit of $1,99 \times 10^{-4}$ to $0,128 \mathrm{~m} /$ day, Flood Plain unit of $0,079 \mathrm{~m} /$ day, and Baturagung Structurally Hill unit of $0,0199 \mathrm{~m} /$ day. Fine sandy clay materials in ex swamp and river units, and flat morphological condition cause the difficulty for groundwater to move, ground is rapidly saturated, so that the velocity of groundwater release is relatively slow. Meanwhile, as a result of relatively water 
proof and massive release rock condition, it causes the groundwater difficult to penetrate the rock and the release velocity is very slow in Baturagung Structurally Hill unit.

(c) Other units have medium permeability coefficient as a result of composing materials condition, which relatively in the form of mix between the results of rock tear down from the surrounding hills. This unstable condition, composed of various materials, gives effect to the variation of aquifer permeability coefficient value. In general, all of these permeability coefficient value variations are included in medium permeability class.

Therefore, based on the result of analysis and classification of groundwater characteristic, whose mapping unit is based on landform unit above, finally it can make research area hydromorphology unit. Hydromorphology unit can be used as the base for planning or groundwater development direction, related to the use for drinking water.

\section{Hydromorphology Units of the Re- search Area}

Based on the result of landform unit interpretation and the result of unconfined groundwater characteristic measurement in the field, and the result of groundwater quality laboratory testing analysis, in fact, from the 13 types of landform units, it can be resulted 16 type of hydromorphology unit in the research area, as listed in Table 7 , and its distribution is presented in Picture 1.

In general, hydromorphology units existing in Bayat have striking unconfined groundwater characteristic (worse) compared to other places in southern Klaten District. Hydromorphology unit of Fluvio Volcanic Plain of Young Merapi in Bayat (Fl V Mm / ECs-t.Dk.As.Va.Ks), is a unit having shallow groundwater characteristic, medium to high of electric conductivity (<1000-2810 mmhos/cm), medium quality of groundwater with the limit of maximum SO and NH content, Va type hydro-chemical, and ${ }^{3}$ medium permeability $( \pm 1.356 \mathrm{~m} /$ day). High value of electric conductivity value may be affected by the region genesis and sedimentation environment of ancient shallow sea in Bayat, so that the content of ancient sea activities residual is high enough. The shallow of water table is affected by the topography in the form of plain, and groundwater movement from the surrounding is submitted in that plain unit. Hydro-chemical type is fresh water, but it was the beginning of cation exchange (Va). Medium permeability is possible caused by the composing material, various and mixed unsortation (mud, sand, gravel).

Hydromorphology unit of Swamp Alluvial Plain in Bayat (Al P Sw / ECt.Dk.Ar.III.Kr) is the unit having the worst condition for its groundwater. High DHL value makes the groundwater brackish to salty, low quality, type III of hydrochemical, and slow permeability. The high value of electric conductivity $(>2500$ $\mathrm{mmhos} / \mathrm{cm}$ ) affecting the low quality is affected by the amount of concentration of diluted substance (Ca, CL, and $\mathrm{SO}$ ), related to the process of rock sedimentation since pre Tertiary era up to now in Bayat region. This is supported by the existence of evaporate water (type III), the residual of sea salt trapped in limestone sedimentation rock, which then affecting 
the surrounding groundwater condition recently. Very intensive process of material sedimentation (sandy clay) as a result of relatively frequent flooding in this unit causes worse aquifer condition with slow permeability. Moreover, its morphology, taking the form of basin (lower than the surrounding), muddy and many organic materials included in the sedimentation. This unit is a unit having the most inappropriate groundwater for the need of drinking water, and it needs more serious management.

Hydromorphology unit of Flood Plain in Bayat (Al P St / ECs.Dk.As.Va.Kr), is the third unit in Bayat relatively has poor groundwater characteristic, and not good to be used. Unconfined groundwater characteristic is almost the same as Fluvio Volcanic Plain in Bayat, medium value of electric conductivity, shallow groundwater, medium quality, Va type and slow aquifer permeability.

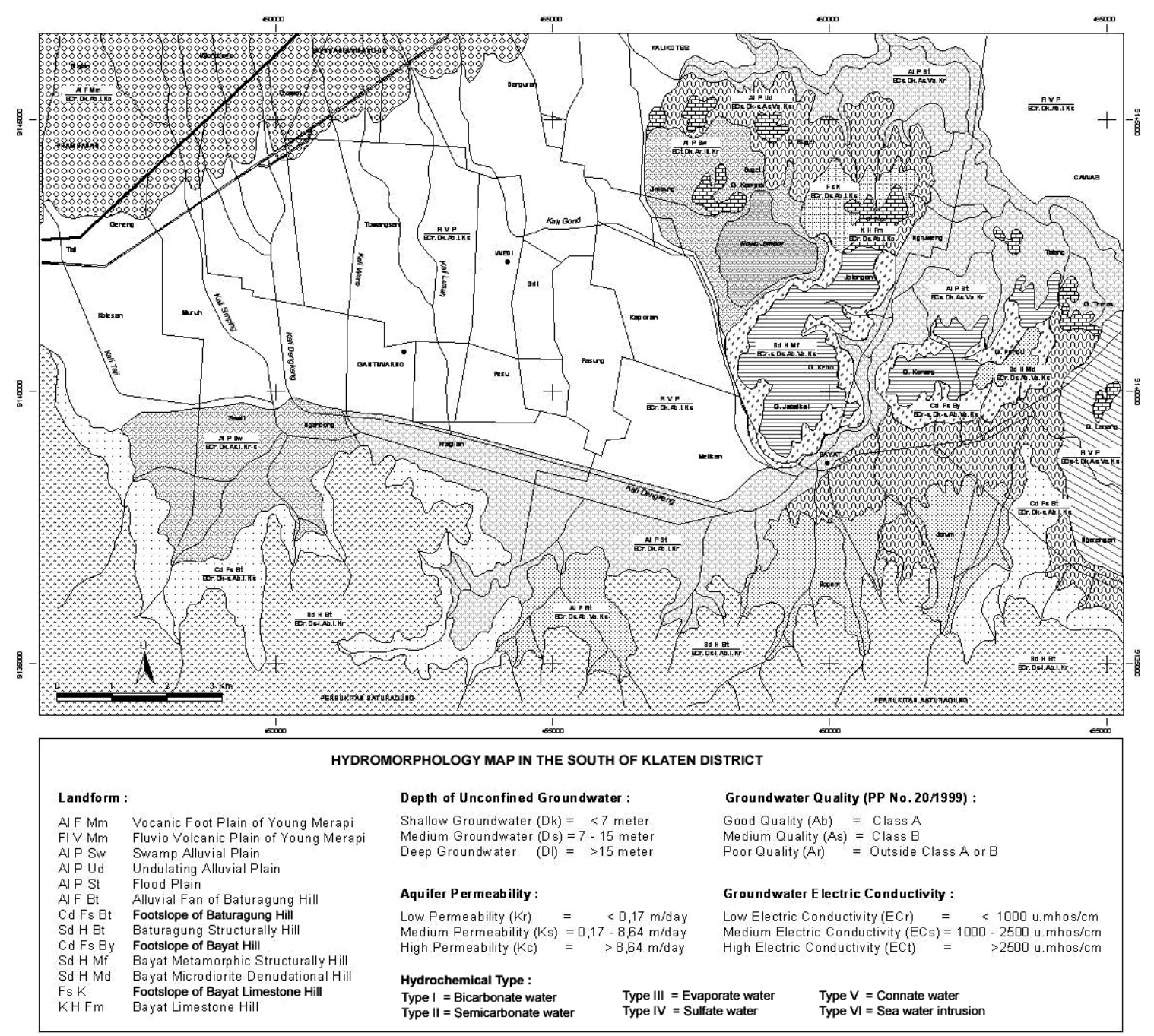

Picture 1. Hydromophology Map in South of Klaten District 


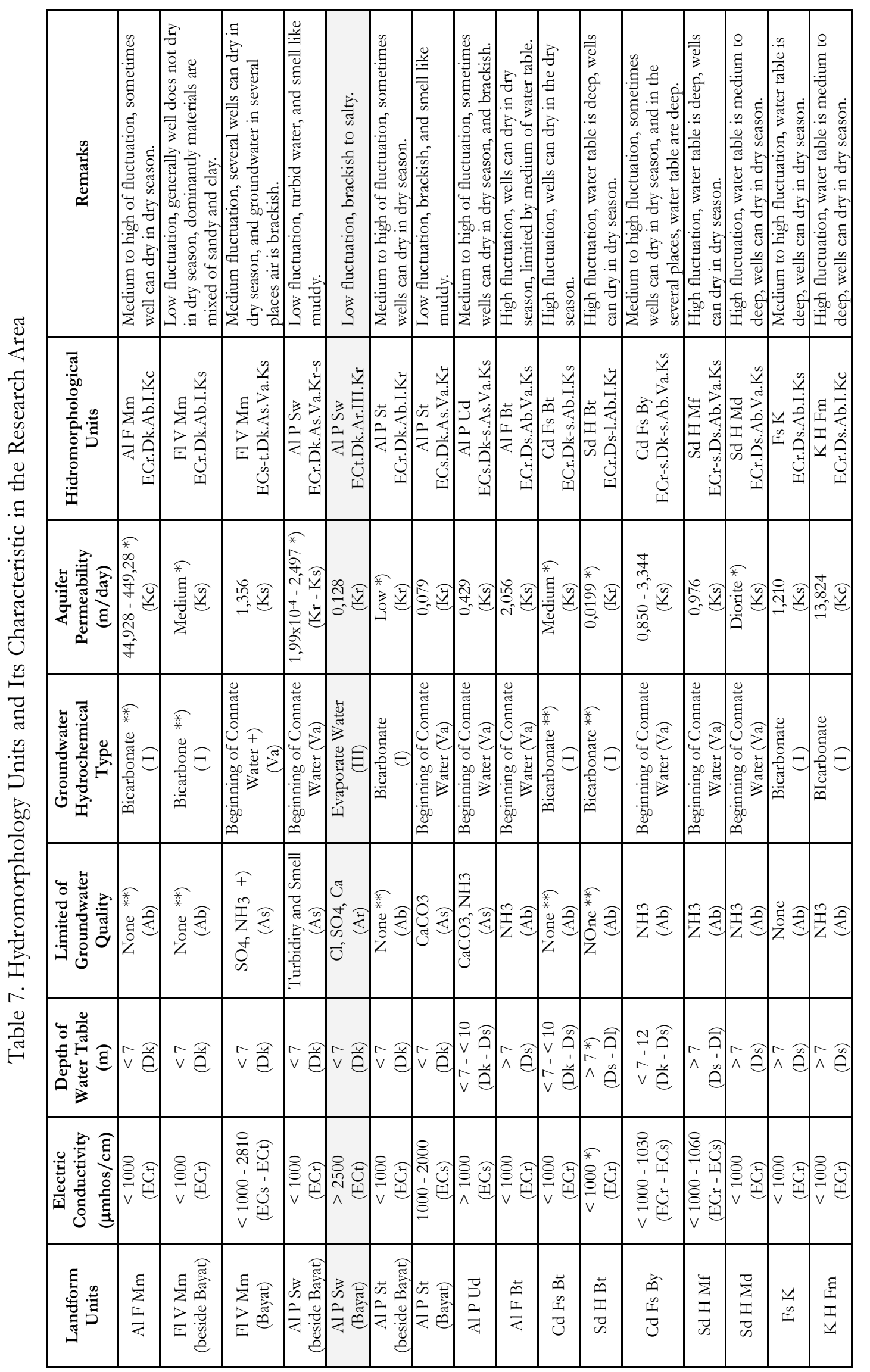




\section{The Recommendation of Unconfined Groundwater Use}

The recommendation showing the direction of unconfined groundwater use to meet people need for drinking water is based on the following consideration:

(a) groundwater quality class for drinking, and the ease of quality limiting factor management;

(b) groundwater electric conductivity value class and the type of groundwater hydro-chemical related to the groundwater genesis;

(c) the level of ease to obtain water resource based on the water table of groundwater; and

(d) aquifer permeability coefficient class as the estimation base for groundwater availability, and groundwater fluctuation as the based of water table change, related to the ease to obtain groundwater in dry season.

Based on those considerations, groundwater unit prioritized to support the need of drinking water of the people is the unit having good groundwater quality $(\mathrm{Ab})$, low of electric conductivity value (ECr), included in the type of bicarbonate or fresh water (type I), easily obtained with simple equipments (shallow water table $=\mathrm{Dk}$ ) and medium to fast ( $\mathrm{Ks}$ to $\mathrm{Kc}$ ) aquifer permeability coefficient, allowing smooth movement of groundwater as the supplier of groundwater. This priority includes: Fluvio Volcanic Plain units (besides Bayat) and Volcanic Foot Plain unit. The next priority is the unit having good quality $(\mathrm{Ab})$, low to medium electric conductivity (ECr to ECs), included in bicarbonate and fresh water (type I and Va), groundwater is easily obtained (shallow to medium groundwater, Dk to Ds), and medium permeability coeffi- cient (Ks). The obstacle is high enough groundwater fluctuation. Included in it is the Foot Slope of Bayat Hill unit; Alluvial Fan of Baturagung Hill unit, and the Foot Slope of Baturagung unit. The effort to manage the environment to reduce the fluctuation of groundwater is using land conservation and infiltration well system.

The unit not becoming the priority is the unit with medium to low groundwater quality (As to Ar), included the beginning of connate water (type $\mathrm{Va}$ ) or evaporate water type (type III), medium to high of electric conductivity (ECs to ECt), shallow to medium groundwater (Dk to Ds), and low to medium aquifer permeability ( $\mathrm{Kr}$ to Ks). The difficult obstacle is the poor water quality as a result of region genesis and sedimentation environment ex ancient sea (lithoral zone). This includes units existing in Bayat: Flood Plain, Undulating Alluvial Plain, Fluvio Volcanic Plain, and Swamp Alluvial Plain units.

\section{CONCLUSION}

(1) Each landform in the research area has variation and distribution of unconfined groundwater characteristic. Therefore, it is true that each landform unit has certain respond to the characteristic and distribution of the unconfined groundwater.

(2) There are the same landforms, but having different unconfined groundwater characteristic between Bayat and other places, i.e. in Fluvio Volcanic Plain, Swamp Alluvial Plain, and Flood Plain units. Such a condition is probably affected by the region genesis, composing material, and its sedimentation environment. Typical in Bayat, related to 
the genesis ex ancient sea activities in the era of Pre Tertiary with shallow sea zone sedimentation environment (lithoral zone), causes the happening of sea water residual trap, so that it is met many brackish or even salty water, high of electric conductivity and low quality (evaporate water).

(3) Based on the analysis of its hydromorphology unit, thus the main priority of the use of unconfined groundwater is for drinking. This exists in Volcanic Foot Plain of Young Merapi and Fluvio Volcanic Plain of Young Merapi units, besides Bayat. The unit not becoming the priority, related to poor quality and hy- dro-chemical type of unconfined groundwater is the units existing in Bayat. This comprises of: Flood Plain, Undulating Alluvial Plain, Fluvio Volcanic Plain of Young Merapi, and Swamp Alluvial Plain units.

\section{ACKNOWLEDGEMENT}

Greatest gratitude I say to UGM Research Institution that has funded this research and great reward is give to my sister M. Widyastuti, who in the beginning became the lecturer in Geography Faculty of Gadjah Mada University, together you help in various activities and also this research.

\section{REFERENCES}

Ahmed A. Murad, and R.V. Krishnamurthy, 2004. Factors Controlling Groundwater Quality in Eastern United Arab Emirats: a Chemical and Isotopic Approach. Journal of Hydrology in the www.elsevier.com/lacate/jhydrol. Vol. 286. Pages 227-235. Elsevier

Appelo, C.A.J. and Postma, D., 1994. Geochemistry, Groundwater and Pollution. A.A. Balkema, Rotterdam, 536p

Bemmelen, R.W. Van, 1970, The Geology of Indonesia, General Geology of Indonesia and Adjecent Archipelagoes, Vol. IA, $2^{\text {nd }}$ editions, Government Printing Office, the Haque

Cartwright, I. And Tamie R. Weaver, 2005. Hydrogeochemistry of the Goulburn Valley Region of the Murray Basin Australia Implikations for Flow paths and Resource Vulnerability. Hydrogeology Journal. Official Journal of the International Association of Hydrogeologists. Volume 13 Number 5-6 October 2005. Pages 752 - 770. Springer Verlag, Berlin, Heidelberg

De Rider, 1972, Hydrogeology of Different Types of Plain, ILRI, Wegeningen

Gabriela-Garcia, M., Margarita-Hidalgo, del V., and Miguel-Blesa, A., 2001. Geochemistry of Groundwater in the Alluvial Plain of Tucuman Province, Argentina, Hydrogeology Journal. Official Journal of the International Association of Hydrogeologists. Volume 9 December 2001. Pages 597 - 610. Springer Verlag, Berlin, Heidelberg

Hadi-Sutomo, 1990, Applied Geology in the Regional Planning in Jiwo Hill and Surrounding of Bayat Region District of Klaten, Tesis, Postgraduate program, Gadjah Mada University, Yogyakarta (in Indonesian language)

Hem, J.D., 1970, Study and Interpretation of the Chemical Characteristic of Natural Water, United State Government Printing Office, New York 
Lawrence, A.R., Gooddy, D.C., Kanatharana, P., Meesilp, W., and Ramnarong, V., 2000. Groundwater Evolution Beneath Hat Yai, a Rapidly Developing City in Thailand. Hydrogeology Journal. Official Journal of the International Association of Hydrogeologists. Volume 8 September 2000. Pages 564 - 575. Springer Verlag, Berlin, Heidelberg

Martinez, D.E., and Bocanegra, E.M., 2002. Hydrogeochemistry and Cation-exchange Processes in the Coastal Aquifer of Mar Del Plata, Argentina. Hydrogeology Journal. Official Journal of the International Association of Hydrogeologists. Volume 10 April 2002. Pages 393 - 408. Springer Verlag, Berlin, Heidelberg

Robert, 1982, Introduction of Structural Geology, John Wiley and Sons, New York

Santosa, L.W., 1995, Unconfined Groundwater Characteristic with Landform Unit Approach in Jiwo Hill of Bayat Region, Thesis, Faculty of Geography, Gadjah Mada University, Yogyakarta (in Indonesian language)

Santosa, L.W., and Widyastuti, 1998, Study of Hidrogeomorphological as Based on Development Planning of Groundwater Resource in South of Klaten District, Report Research, Research Instituion, Gadjah Mada University, Yogyakarta (in Indonesian language)

Soemarto C.D., 1988, Technical Hydrology, Usaha Nasional, Surabaya (in Indonesian language)

Sutikno, 1989, Study of Landform to Zoning of Clean Water System in Serang Watershed Kulonprogo, Research Report, Faculty of Geography, Gadjah Mada University, Yogyakarta (in Indonesian language)

Sutikno, 1992, Geomorphological Approach to Unconfined Groundwater Study in Sangiran Hill Area, District of Sragen, Central Java, Research Report, Faculty of Geography, Gadjah Mada University, Yogyakarta (in Indonesian language)

Todd, D.K., 1980, Groundwater Hydrology, John Wiley and Sons, New York

Umar-Asad, Umar-Rashid, and Ahmad, M.S., 2001. Hydrogeological and Hydrochemical Framewrok of Regional Aquifer System in Kali Ganga Sub-Basin, India. Journal on Environmental Geology in the www.proquest.com. Volume 40, February 2001. Pages 602 - 611. Applied Science and Technology Plus

Widiyanto and Jamulya, 1993, Paleo-geomorphology in South of Gantiwarno Sub District, District of Klaten, Research Report, Faculty of Geography, Gadjah Mada University, Yogyakarta (in Indonesian language) 